\title{
Serum vitamin D levels in children with recurrent tonsillopharyngitis
}

\author{
Abdulhamit Collak' ${ }^{1}$, Abdulkadir Bozaykut ${ }^{1}$, Bilge Demirel ${ }^{1}$, \\ Rabia Gonul Sezer', Lale Pulat Seren ${ }^{1}$, Mahmut Dogru² \\ ${ }^{1}$ Department of Pediatrics, Zeynep Kamil Maternity and Children's Diseases Training and Research Hospital, Istanbul, Turkey; \\ ${ }^{2}$ Department of Pediatric Allergy and Immunology, Zeynep Kamil Maternity and Children's Diseases Training and Research \\ Hospital, Istanbul, Turkey
}

\begin{abstract}
OBJECTIVE: In this study, we aimed to compare vitamin D levels of children with recurrent tonsillopharingitis and healthy controls, and investigate the relationship between sociodemographic characteristics and serum vitamin D levels.

METHODS: Children with recurrent tonsillopharingitis and healthy controls aged between 2, and 12 years who consulted to the outpatient clinics of Zeynep Kamil Maternity and Children's Diseases Training and Research Hospital from January to October 2012 were included in this study. Serum $25(\mathrm{OH})$ vitamin D levels were studied by tandem mass spectroscopy (tandem ms) method. Risk factors which might be associated with vitamin D levels were questioned. Ethical aproval was obtained from the Ethics Committee of Zeynep Kamil Maternity and Children's Diseases Training and Research Hospital and informed consent from the parents of the children.
\end{abstract}

RESULTS: A total of 147 children; 74 (50.3\%) patients and 73 (49.7\%) controls were included in our study. Age, gender and demographic characteristics did not differ significantly between the two groups. Vitamin $D$ levels in patients with recurrent tonsillopharingitis and controls were $19.7 \pm 8.7 \mathrm{ng} / \mathrm{ml}$ and $23.6 \pm 9.2 \mathrm{ng} / \mathrm{ml}$, respectively $(p<0.01)$. Although duration of vitamin $D$ usage was shorter in children with recurrent tonsillopharingitis, this difference was not statistically significant ( $p>0.05)$.

CONCLUSION: Vitamin D levels in children with $\geq 7$ recurrent episodes of tonsillophargitis within the preceeding year were significantly lower compared to the control group. We believe that serum vitamin $D$ levels should be checked in children with recurrent tonsillopharingitis and deficiencies should be treated.

Key words: $25-\mathrm{OH}$ vitamin $\mathrm{D}$, infection, recurrent tonsillopharyngitis, vitamin D

$\mathrm{T}$ onsillopharyngitis is an important health problem in childhood because of potential development of its suppurative complications (peritonsillary abscess, sinusitis, mastoiditis, otitis media, endocarditis, meningitis, and pneumonia) caused by group A beta- hemolytic streptococci, 
and also non-suppurative complications, in addition to the difficulties in the identification of the etiological agent (bacterial vs viral). In the literature, recurrent tonsillopharyngitis is defined as 7 or more well-documented, clinically important, adequately treated episodes of tonsillopharyngitis in the preceeding year or 3 or more such episodes in each of the preceeding 3 years or 5 or more such episodes in the preceeding 2 years [1]. In the pediatric population tonsillopharyngitis is an important morbidity which adversely affects quality of life of the children, and parents because of its frequently recurrent symptoms, its treatment, and potential complications, and school absence it causes. In the United States of America in the year 1996 one of every 100 children had not reportedly attended their schools for a total of 152 days because of upper respiratory tract infections [2].

Comprehension of antiproliferative, prodifferentiative, proapoptotic, and immunomodulator functions of vitamin $\mathrm{D}$ whose deficiency was associated with only rickets for a long time has led to reconsideration of this vitamin regarding its newly discovered beneficial effects [3]. In studies performed, the role of vitamin $\mathrm{D}$ in decreasing the risks of many chronic diseases including prominently some types of cancer, followed by many autoimmune, infectious, and cardiovascular diseases are remarkable [4]. As revealed in many studies, vitamin $\mathrm{D}$ deficiency increases the risk of contracting many infections [5]. Vitamin D deficiency is reportedly a risk factor for the development of tuberculosis, otitis media, upper respiratory tract, and gripal infections $[6,7,8]$.

In this study, we aimed to compare vitamin $\mathrm{D}$ levels in children who had recurrent episodes of tonsillopharyngitis, and in healthy children, and investigate the correlation between sociodemographic characteristics, and vitamin D levels.

\section{MATERIALS AND METHODS}

This prospective study included children aged between 2-12 years with recurrent tonsillopharingitis and their age-matched healthy controls who consulted to the outpatient clinics of Zeynep Kamil Maternity and Children's Diseases Training and
Research Hospital from January to October 2012. The number of episodes of infections were determined based on patients' history of recurrent diagnoses of tonsillopharyngitis, hospital files, their prescriptions, and admission complaints. Demographic characteristics of the children, and their duration of vitamin D therapy during infancy were recorded.

Inclusion criteria for the study group were as follows: suffering from 7 or more well-documented, clinically important, and adequately treated episodes of tonsillopharyngitis in the preceeding year or 5 or more such episodes in each of the preceeding years or 3 or more such episodes in each of the 3 preceeding years. For the control group inclusion criteria were determined as experiencing less than 7 such episodes in the preceeding year, absence of any known chronic disease or any disease which might effect vitamin $\mathrm{D}$ metabolism or vitamin $\mathrm{D}$ therapy.

Blood samples were drawn from the children included in the study in order to analyze serum 25 $(\mathrm{OH})$ D levels. Serum $25(\mathrm{OH})$ vitamin D levels were analyzed using LC/MS/MS method which has been accepted as a reference method with higher sensitivity, and specificity. Waters ${ }^{\oplus}$ Micromass ${ }^{\circledR}$ Quattro Premier XE ${ }^{\mathrm{rm}}$ Tandem Quadrupole Mass Spectrometer was used for analyses.

Vitamin D deficiency, insufficiency, and adequacy were defined as the detection of vitamin $\mathrm{D}$ levels of $<20 \mathrm{ng} / \mathrm{ml}, 20-32 \mathrm{ng} / \mathrm{ml}$, and $32-100 \mathrm{ng} / \mathrm{ml}$, respectively. Study population were divided into 3 groups based on the aforesaid vitamin D levels as groups with deficient, insufficient, and adequate vitamin D levels. Parameters as age, frequency of tonsillopharyngitis etc. were compared between groups.

SPSS (Statistical Package for Social Sciences 15; SPSS Inc., Chicago, IL, USA) program was used to evaluate study data. In intergroup comparisons for categorical variables chi-square, for comparisons of mean values between two or among three groups, Mann Whitney-U, and Kruskal-Wallis tests were used, respectively. The results were evaluated at accepted level of significance of $p<0.05$, and within 95\% confidence limit.

The approval for the conduction of the study was obtained beforehand from The Ethics Com- 
mittee of Zeynep Kamil Maternity, and Children's Diseases Training and Research Hospital. Enlightened consent forms were signed by the parents who volunteered to participate in the study.

\section{RESULTS}

A total of 147 children; 74 (50.3\%) patients and 73 (49.7\%) controls were included in the study. Age, gender and demographic characteristics did not differ significantly between the two groups. Vitamin D levels in patients with recurrent tonsillopharingitis and controls were $19.7 \pm 8.7 \mathrm{ng} / \mathrm{ml}$ and $23.6 \pm 9.2$ $\mathrm{ng} / \mathrm{ml}$, respectively $(\mathrm{p}<0.01)$. Although duration of vitamin $\mathrm{D}$ usage was shorter in children with recur- rent tonsillopharingitis, this difference was not statistically significant $(\mathrm{p}>0.05)$.

A total of 147 (girls, $n=71 ; 48.3 \%$ ) patients were included in the study. Study, and control groups consisted of $74(50.3 \%)$ patients, and 73 (49.7\%) healthy individuals, respectively. Study, and control groups were not significantly different as for age, gender, number of siblings, and duration of vitamin $\mathrm{D}$ use. In the recurrent tonsillopharyngitis group, vitamin $\mathrm{D}$ level was detected to be significantly lower when compared to the control group $(p<0.01)$. Duration of vitamin D use was shorter than the control group without any statistically significant difference between groups ( $p>0.05)$ (Table 1).

TABLE 1. Comparison of vitamin D levels in patients who suffered from frequent episodes of tonsillopharyngitis, and the control group

\begin{tabular}{|c|c|c|c|c|c|c|c|}
\hline & \multicolumn{3}{|c|}{ Control group } & \multicolumn{3}{|c|}{ Study group } & \multirow[t]{2}{*}{$\mathrm{p}$} \\
\hline & Mean & SD & Median & Mean & SD & Median & \\
\hline Age (mos) & 65.72 & 28.11 & 60.00 & 67.36 & 29.75 & 60.00 & 0.782 \\
\hline Number of episodes of tonsillopharyngitis & 2.54 & 1.55 & 2.00 & 8.42 & 1.55 & 8.00 & 0.0001 \\
\hline Vitamin D level (ng/ml) & 23.62 & 9.22 & 23.00 & 19.73 & 8.77 & 18.00 & 0.009 \\
\hline Duration of vitamin D therapy (mos) & 9.91 & 5.81 & 12.00 & 9.38 & 6.29 & 12.00 & 0.693 \\
\hline
\end{tabular}

SD: Standard deviation.

TABLE2. Comparison of demographic characteristics of the patients based on vitamin D levels

\begin{tabular}{|c|c|c|c|c|c|c|c|c|c|c|}
\hline & \multicolumn{3}{|c|}{$\begin{array}{l}\text { Vitamin D deficiency } \\
\quad<20 \mathrm{ng} / \mathrm{ml}\end{array}$} & \multicolumn{3}{|c|}{$\begin{array}{l}\text { Vitamin D insufficiency } \\
\qquad 20-32 \mathrm{ng} / \mathrm{ml}\end{array}$} & \multicolumn{3}{|c|}{$\begin{array}{l}\text { Vitamin D adequacy } \\
32-100 \mathrm{ng} / \mathrm{ml}\end{array}$} & \multirow[t]{2}{*}{$\mathrm{p}$} \\
\hline & $\mathrm{n}$ & $\%$ & Mean \pm SD & $\mathrm{n}$ & $\%$ & Mean \pm SD & $\mathrm{n}$ & $\%$ & Mean \pm SD & \\
\hline Patients & 63 & 42.9 & & 74 & 50.3 & & 10 & 6.8 & & 0.0001 \\
\hline Age (mos) & & & $70.8 \pm 29.6$ & & & $65.2 \pm 28.5$ & & & $48.5 \pm 17.3$ & 0.05 \\
\hline Gender (Female) & 34 & 47.9 & & 34 & 47.9 & & 3 & 4.2 & & 0.31 \\
\hline \multicolumn{11}{|l|}{ Episodes of URTI } \\
\hline$<7 / \mathrm{yr}$ & 25 & 33.8 & & 42 & 56.8 & & 7 & 9.5 & & 0.06 \\
\hline$\geq 7 / y r$ & 38 & 52.1 & & 32 & 43.8 & & 3 & 4.1 & & \\
\hline Levels of vitamin $D(\mathrm{ng} / \mathrm{ml})$ & & & $13.8 \pm 4.15$ & & & $25.4 \pm 3.36$ & & & $43.2 \pm 10.11$ & 0.0001 \\
\hline
\end{tabular}

SD: Standard deviation; URTI: Upper respiratory tract infection. 
Vitamin D level was deficient, insufficient, and adequate in $42.9(n=63), 50.3(n=74)$, and $6.8 \%$ $(n=10)$ of the patients in the study population. Although in patients with vitamin $\mathrm{D}$ deficiency, household members, and episodes of tonsillopharyngitis were more numerous, and the duration of vitamin D use was the shortest relative to the control group without any significant difference between groups as for demographic characteristics $(p>0.05)$ (Table 2).

\section{DISCUSSION}

Although our country takes advantage of the sunlight abundantly, vitamin $\mathrm{D}$ deficiency still continues to be an important health problem affecting pregnants, babies, and adolescents American Academy of Pediatrics recommends administration of 400 IU oral vitamin D supplementation beginning from the neonatal period, and continuing all along the infancy [9]. Although vitamin D supplementation program has been implemented in our country, especially in rural areas vitamin D deficiency is frequently encountered [10].

Detection of vitamin $\mathrm{D}$ receptors in many tissues of the body has led to the conduction of new studies on the functions, and correlations of vitamin $\mathrm{D}$ which plays an important role in the bone-mineral metabolism with various disease states [11]. Vitamin D exerts its effects through activation of vitamin $\mathrm{D}$ receptors which regulate transcriptions of target genes responsible for biological effects of its active form 1,25 (OH)2 D [12]. The presence of the receptor in immune system cells (dendritic cells, B-lymphocytes, T-lymphocytes, NK-cells, monocytes) has been demonstrated. Besides, genetic polymorphism in these cells which lead to modifications in the functions of immune cells has been indicated $[13,14,15,16]$. Presence of vitamin D receptors in immune system cells, and various regulatory effects of these cells induced by stimulation of these receptors demonstrate the correlation between vitamin $\mathrm{D}$, and especially with immune system of the upper respiratory tract [17].

Vitamin D has important roles in fighting against infectious agents, and in individuals with vitamin D deficiency, increase in the predisposition, and frequency of especially respiratory tract infections has been demonstrated. In their case-controlled studies performed among Ethiopian children less than 5 years of age with rickets, Muhe et al.[18] reported an existence of a correlation between vitamin $\mathrm{D}$ deficiency, and development of pneumonia. Wayse et al.[19] reported that in India, subclinical vitamin $\mathrm{D}$ insufficiency in children less than 5 years of age is an important risk factor for the development of serious lower respiratory tract infection. In their series, Cannell et al.[20] indicated that the incidence of viral respiratory tract infection had increased in cases with vitamin $\mathrm{D}$ insufficiency. Recurrent nature of acute tonsillopharyngitis has been reported in $10-15 \%$ of the pediatric cases $[21,22,23]$. Yildiz et al.[11] detected recurrent tonsillopharyngitis in $4.7 \%$ of the children who referred to the polyclinics of general pediatrics In the literature, lower vitamin $D$ levels were detected in children who had suffered from frequent episodes of tonsillopharyngitis [11, 24]. In our study, we detected lower vitamin D levels in children who suffered from frequent episodes of tonsillopharyngitis in consistent with the literature findings.

Yildiz et al.[11] reported that in patients with insufficient vitamin D levels, annual incidence rates of disease were markedly higher, and indicated that its incidence decreased directly proportional with increases in serum $25-(\mathrm{OH})$ vitamin D levels. In the same study, despite serum vitamin $D$ levels within normal limits in cases who had frequent episodes of tonsillopharyngitis, and in the control group, serum 25- $(\mathrm{OH})$ vitamin D levels were significantly lower in the recurrent tonsillopharyngitis group $(142.7 \pm 68.1 \mathrm{nmol} / \mathrm{L})$ when compared with the control group $(192.3 \pm 56.1 \mathrm{nmol} / \mathrm{L})$.

In studies performed in adult patients similar outcomes have been found. Nseir et al.[25] detected significantly lower serum $25(\mathrm{OH})$ vitamin $\mathrm{D}$ levels in the group of patients who frequently suffered from group A beta-hemolytic streptococcal tonsillopharyngitis. Ginde et al.[26] detected the rate of URTI as 24,20 , and $17 \%$ in patients with serum $25(\mathrm{OH})$ vitamin D levels of $<10 \mathrm{ng} / \mathrm{mL}, 10$ $30 \mathrm{ng} / \mathrm{ml}$, and $\geq 30 \mathrm{ng} / \mathrm{ml}$, respectively with statisti- 
cally significant differences between groups. These outcomes demonstrate decrease in the frequency of tonsillopharyngitis in parallel with an increase in vitamin D levels.

However, some studies have demonstrated lack of any correlation between vitamin $\mathrm{D}$ levels, and frequent infections. In a study performed by Aydin et al.,[27] the authors couldn't find a significant difference between patients who experienced frequent episodes of tonsillitis and thus underwent tonsellectomies and the control group regarding serum 25 $(\mathrm{OH})$ vitamin D levels. Detection of similar serum vitamin $\mathrm{D}$ levels in both groups was interpreted as lack of any correlation between recurrent tonsillopharyngitis, and serum vitamin D levels. Similarly, in other studies, various units of measurement, and cut-off values have been used for the definition of vitamin $\mathrm{D}$ deficiency. Since the definition of vitamin D deficiency has not been standardized, it is hardly possible to compare outcomes of our study with those of the others.

Serum $25(\mathrm{OH})$ vitamin $\mathrm{D}$ levels less than 20 $\mathrm{ng} / \mathrm{ml}(50 \mathrm{nmol} / \mathrm{L})$ are defined as vitamin $\mathrm{D}$ deficiency, while serum vitamin $\mathrm{D}$ levels protective against infections, and those inducing immune system have not been clearly established yet [28, $29]$. In our study, vitamin D levels were deficient, insufficient, and adequate in $42.9,50.3$, and $6.8 \%$ of the cases, respectively. The study population was divided into 3 groups as vitamin $\mathrm{D}$ deficient, insufficient, and adequate groups, and any significant difference was not detected between groups as for demographic characteristics, number of episodes of tonsillopharyngitis experienced, and duration of vitamin D use.

Vitamin D levels in children are influenced by maternal and environmental factors as daily diet, and sunlight $[11,27]$. Protective role of vitamin D support against some diseases, predominantly upper, and lower respiratory tract infections in pregnancy, early childhood, and advanced age has been demonstrated [30, 31, 32]. However, controversial outcomes have been reported against protective role of vitamin $\mathrm{D}$ in upper respiratory tract infections $[33,34,35]$. Li- $\mathrm{Ng}$ et al. have demonstrated that daily 2000 IU vitamin D supplement for the adults during winter months did not decrease the frequency, and severity of URTI [34]. Avenell et al. detected that administration of daily 800 IU vitamin D supplement decreased the incidence of infection at a rate of $10-15 \%$ without any statistically significant difference [35]. To reveal the correlation between vitamin $\mathrm{D}$, and respiratory tract infection clearly, studies standardized according to seasons, dietary habits, the amount of sunlight exposure received by the countries, and regional clothing habits are needed.

One limitation of our study is that only a single measurement of vitamin D levels which show seasonal variations during the study period may not fully reflect vitamin D levels of the children.

In our country, vitamin D deficiency is an important public health problem which is often seen in pediatric cases with frequent tonsillopharyngitis. We think that in children with frequent tonsillopharyngitis, as a result of treatment of deficiencies detected with measurement of serum vitamin $D$ levels, frequency of diseases, and healthcare expenses will decrease.

Conflict of Interest: No conflict of interest was declared by the authors.

Financial Disclosure: The authors declared that this study has received no financial support.

\section{REFERENCES}

1. Vital and Health Statistics. Current estimates from the national health interview survey, 1996. Series 10, No. 200. Atlanta GA: Centers for Disease Control and Prevention, National Center for Health Statistics, October 1999.

2. Paradise JL, Bluestone CD, Colborn DK, Bernard BS, Rockette HE, Kurs-Lasky M. Tonsillectomy and adenotonsillectomy for recurrent throat infection in moderately affected children. Pediatrics 2002;110:7-15. CrossRef

3. Özkan B, Döneray H. D vitamininin iskelet sistemi dışı etkileri. Çocuk Sağlığı ve Hastalıkları Dergisi 2011;54:99-100.

4. Holick MF. Vitamin D deficiency. N Engl J Med 2007;357:26681. CrossRef

5. Cannell JJ, Vieth R, Umhau JC, Holick MF, Grant WB, Madronich $\mathrm{S}$, et al. Epidemic influenza and vitamin D. Epidemiol Infect 2006;134:1129-40. CrossRef

6. Hewison M. Vitamin D and the immune system: new perspectives on an old theme. Endocrinol Metab Clin North Am 
2010;39:365-79. CrossRef

7. Walker VP, Modlin RL. The vitamin D connection to pediatric infections and immune function. Pediatr Res 2009;65:106R113R. CrossRef

8. Hughes DA, Norton R. Vitamin D and respiratory health. Clin Exp Immunol 2009;158:20-5. CrossRef

9. Misra M, Pacaud D, Petryk A, Collett-Solberg PF, Kappy M; Drug and Therapeutics Committee of the Lawson Wilkins Pediatric Endocrine Society. Vitamin D deficiency in children and its management: review of current knowledge and recommendations. Pediatrics 2008;122:398-417. CrossRef

10. Hatun Ş, Bereket A, Çalıkoğlu AS, Özkan B. Günümüzde D vitamini yetersizliği ve nutrisyonel rikets. Çocuk Sağlığ ve Hastalıklar1 Dergisi 2003;46:224-41.

11. Yildiz I, Unuvar E, Zeybek U, Toptas B, Cacina C, Toprak S, et al. The role of vitamin $\mathrm{D}$ in children with recurrent tonsillopharyngitis. Ital J Pediatr 2012;38:25. CrossRef

12. Dusso AS, Brown AJ, Slatopolsky E. Vitamin D. Am J Physiol Renal Physiol 2005;289:F8-28. CrossRef

13. Deluca HF, Cantorna MT. Vitamin D: its role and uses in immunology. FASEB J 2001;15:2579-85. CrossRef

14. Thien R, Baier K, Pietschmann P, Peterlik M, Willheim M. Interactions of 1 alpha,25-dihydroxyvitamin D3 with IL-12 and IL-4 on cytokine expression of human T lymphocytes. J Allergy Clin Immunol 2005;116:683-9. CrossRef

15. Uitterlinden AG, Fang Y, Van Meurs JB, Pols HA, Van Leeuwen JP. Genetics and biology of vitamin D receptor polymorphisms. Gene 2004;338:143-56. CrossRef

16. Hewison M. Vitamin D and the immune system: new perspectives on an old theme. Endocrinol Metab Clin North Am 2010;39:365-79. CrossRef

17. Bartley J. Vitamin D, innate immunity and upper respiratory tract infection. J Laryngol Otol 2010;124:465-9. CrossRef

18. Muhe L, Lulseged S, Mason KE, Simoes EA. Case-control study of the role of nutritional rickets in the risk of developing pneumonia in Ethiopian children. Lancet 1997;349:1801-4. CrossRef

19. Wayse V, Yousafzai A, Mogale K, Filteau S. Association of subclinical vitamin $\mathrm{D}$ deficiency with severe acute lower respiratory infection in Indian children under $5 \mathrm{y}$. Eur J Clin Nutr 2004;58:563-7. CrossRef

20. Cannell JJ, Vieth R, Umhau JC, Holick MF, Grant WB, Madronich $S$, et al. Epidemic influenza and vitamin D. Epidemiol Infect 2006;134:1129-40. CrossRef

21. Gerber MA. Pharyngitis. In: Long SS, Pickering LK, Prober CG, editors. Principles and Practice of Pediatric Infectious Diseases, 3th ed. Philadelphia: Churchil Livingstone; 2008. p. 206 13. CrossRef
22. Hayden GF, Turner RB. Pharyngitis. In: Jenson HB, Baltimore RS, editors. Pediatric Infectious Diseases Principles and Practice, 2th ed. Philadelphia: W.B. Saunders Company; 2002. p. 711-20.

23. Ünüvar E. Tekrarlayan üst solunum yolu enfeksiyonu olan çocuğun değerlendirilmesi. Çocuk Enf Derg 2007;1(Özel Say1):43-5.

24. Reid D, Morton R, Salkeld L, Bartley J. Vitamin D and tonsil disease-preliminary observations. Int J Pediatr Otorhinolaryngol 2011;75:261-4. CrossRef

25. Nseir W, Mograbi J, Abu-Rahmeh Z, Mahamid M, Abu-Elheja $\mathrm{O}$, Shalata $\mathrm{A}$. The association between vitamin $\mathrm{D}$ levels and recurrent group A streptococcal tonsillopharyngitis in adults. Int J Infect Dis 2012;16:735-8. CrossRef

26. Ginde AA, Mansbach JM, Camargo CA Jr. Association between serum 25-hydroxyvitamin D level and upper respiratory tract infection in the Third National Health and Nutrition Examination Survey. Arch Intern Med 2009;169:384-90. CrossRef

27. Aydın S, Aslan I, Yıldız I, Ağaçhan B, Toptaş B, Toprak S, et al. Vitamin D levels in children with recurrent tonsillitis. Int J Pediatr Otorhinolaryngol 2011;75:364-7. CrossRef

28. Grant WB, Holick MF. Benefits and requirements of vitamin D for optimal health: a review. Altern Med Rev 2005;10:94-111.

29. Holick MF. Vitamin D status: measurement, interpretation, and clinical application. Ann Epidemiol 2009;19:73-8. CrossRef

30. Boucher BJ, John WG, Noonan K. Hypovitaminosis D is associated with insulin resistance and beta cell dysfunction. Am J Clin Nutr 2004;80:1666-7.

31. Munger KL, Levin LI, Hollis BW, Howard NS, Ascherio A. Serum 25-hydroxyvitamin D levels and risk of multiple sclerosis. JAMA 2006;296:2832-8. CrossRef

32. Nursyam EW, Amin Z, Rumende CM. The effect of vitamin $\mathrm{D}$ as supplementary treatment in patients with moderately advanced pulmonary tuberculous lesion. Acta Med Indones 2006;38:3-5.

33. Laaksi I, Ruohola JP, Mattila V, Auvinen A, Ylikomi T, Pihlajamäki H. Vitamin D supplementation for the prevention of acute respiratory tract infection: a randomized, double-blinded trial among young Finnish men. J Infect Dis 2010;202:809-14.

34. Li-Ng M, Aloia JF, Pollack S, Cunha BA, Mikhail M, Yeh J, et al. A randomized controlled trial of vitamin D3 supplementation for the prevention of symptomatic upper respiratory tract infections. Epidemiol Infect 2009;137:1396-404. CrossRef

35. Avenell A, Cook JA, Maclennan GS, Macpherson GC. Vitamin D supplementation to prevent infections: a sub-study of a randomised placebo-controlled trial in older people (RECORD trial, ISRCTN 51647438). Age Ageing 2007;36:574-7. CrossRef 